Original Research Paper

\title{
In Vitro Immunomodulatory and Cytotoxic Potentials of Faloak (Sterculia quadrifida R.Br.) Bark
}

\author{
1,2 Triana Hertiani, ${ }^{3}$ Purwantiningsih, ${ }^{4}$ Aji Winanta, ${ }^{5}$ Widyandani Sasikirana, \\ ${ }^{6}$ Rima Munawaroh, ${ }^{1}$ Erna Prawita Setyowati, ${ }^{3}$ Retno Murwanti and ${ }^{7,8}$ Siswadi \\ ${ }^{1}$ Department of Pharmaceutical Biology, Faculty of Pharmacy, Universitas Gadjah Mada, Yogyakarta, Indonesia \\ ${ }^{2}$ Centre for Natural Antiinfective Research, Faculty of Pharmacy, Universitas Gadjah Mada, Yogyakarta, Indonesia \\ ${ }^{3}$ Department of Pharmacology and Clinical Pharmacy, Faculty of Pharmacy, \\ Universitas Gadjah Mada, Yogyakarta, Indonesia \\ ${ }^{4}$ Department of Pharmaceutical Biology, Faculty of Medicine and Health Sciences, \\ Universitas Muhammadiyah Yogyakarta, Yogyakarta, Indonesia \\ ${ }^{5}$ Pharmacy Study Program, Faculty of Medicine, Diponegoro University, Semarang, Indonesia \\ ${ }^{6}$ Department of Pharmaceutical Biology, Faculty of Pharmacy, \\ Universitas Muhammadiyah Surakarta, Surakarta, Indonesia \\ ${ }^{7}$ Kupang Environment and Forestry Research and Development Institute, Kupang, Indonesia \\ ${ }^{8}$ Banjarbaru Environment and Forestry Research and Development Institute, Banjarbaru, Indonesia
}

\author{
Article history \\ Received: 09-08-2019 \\ Revised: 22-10-2019 \\ Accepted: 05-11-2019 \\ Corresponding Author: \\ Triana Hertiani \\ Department of Pharmaceutical \\ Biology, Faculty of Pharmacy, \\ Universitas Gadjah Mada, \\ Yogyakarta, Indonesia \\ Email: hertiani@ugm.ac.id
}

\begin{abstract}
Faloak (Sterculia quadrifida R.Br., Sterculiaceae) is an Indonesia indigenous plant widely used as a traditional remedy for various health complaints. This study aimed to explore the immunomodulatory and cytotoxicity potentials of Faloak bark by using in vitro techniques. Barks was extracted using water, ethanol and ethanol: water (1:1) separately. Colorimetric analysis was used for the determination of the total phenolic and the total flavonoid contents. Immunomodulator activities of the extracts were evaluated by studying their effects on mice macrophages and lymphocytes using in vitro methods, while the cytotoxicity potential was evaluated against Vero and HepG2 cell lines. The active extract was further fractionated and tested using different cell lines by the MTT method. Data were analyzed using one-way ANOVA and LSD tests, with a 95\% confidence level $(p<0.05)$. All extracts significantly increased the phagocytosis of macrophages compared to that of control in a concentrationdependent manner. However, all the extracts exhibited the Stimulation Index value of $<2$, which indicated no effect on lymphocyte proliferation. The ethyl acetate fraction showed the highest activity against T47D, MCF7 and HepG2 cells with IC50 9.56; 7.62; $3.24 \mu \mathrm{g} / \mathrm{mL}$ and the Selectivity Index (against Vero cells) as follows, $2.01 ; 2.52 ; 5.94$, respectively. Faloak bark extracts can stimulate macrophage phagocytosis activity in vitro, which positively correlates to the contents of flavonoids and other phenolic compounds. The ethyl acetate fraction exhibited the highest activity, which supports its potency as cancer chemopreventive herbal medicine.
\end{abstract}

Keywords: Sterculia quadrifida, Faloak, Immunomodulator, Cytotoxic

\section{Introduction}

Immunomodulators include substances that can modulate the body's immune system responsible for preventing and protecting against infection as well as contributing toward modulation of homeostasis (Bhat et al., 2015). Faloak (Sterculia quadrifida R.Br.) is one of the indigenous species of Indonesia that has been used as a natural remedy by local people in East Nusa Tenggara.
The bark is used for broad therapeutic purposes, including as a hepatoprotective agent (Ranta, 2011). However, scientific evidence in this regard is limited. Local people believe that regular drinking Faloak decoction can increase stamina. The preliminary research on its phytochemical contents has demonstrated the existence of alkaloids, steroids, triterpenoids, phenolics compounds and saponins (Siswadi, 2015; Siswadi et al., 2014). Those compounds may contribute to the pharmacological 
effects of faloak. Several plant phenolics compounds have been reported to exert antioxidant and antiinflammatory activities. This group of compounds can modulate immune responses (Magrone et al., 2016; Santangelo et al., 2007).

Extracts resulted from a decoction (in water) and maceration (in ethanol and a mixture of ethanol-water) were used in this study. Decoction refers to local people's usage of the bark. Considering that ethanol has a wider extraction range compared with water, the use of different extraction solvents results in different chemical profiles and may cause different biological activities. Our preliminary study has revealed the ethanol extract potentials as DPPH radical scavenging and in enhancing macrophage phagocytosis (Hertiani et al., 2017).

As part of phytochemical analyses, the total phenolic and the total flavonoid contents were determined for each extract. Immunomodulator activities of the extracts were evaluated by studying their effects on mice macrophages and lymphocytes using in vitro methods, while the cytotoxicity potential was evaluated against Vero and HepG2 cell lines. Vero represents normal cells, while HepG2 represents hepatocellular carcinoma. Those cells were selected to represent the extract potency as hepatoprotective. The active extract was further fractionated and tested using different cell lines by the MTT method. Phytochemical analyses of the extracts were evaluated to predict compounds responsible for the activity.

This study results support faloak bark usage as an herbal medicine for cancer chemoprevention. It may help the researcher to uncover the critical areas of finding the scientific proof of this herb by the local people as hepatoprotective that many researchers were unable to explore yet. Thus a new insight on how this bark may beneficial for that respective effect may be arrived at and can be used as a scientific background for further study.

\section{Materials and Methods}

\section{Materials}

Faloak barks ( $S$. quadifrida R.Br.) were collected from Kupang, East Nusa Tenggara, Indonesia. Extraction solvents used in this study were ethanol (technical grade) and distilled water. Materials used for phytochemical analyses included acetone, formic acid, methanol (pro analyses, Merck, Germany); spraying reagents used were $\mathrm{AlCl}_{3}, \mathrm{Ce}\left(\mathrm{SO}_{4}\right)_{2}, \mathrm{DPPH}, \mathrm{NH}_{4} \mathrm{OH}$ (Merck, Germany); precoated TLC silica gel 60 RP-18 $\mathrm{F}_{254}$ (Merck, Germany), Folin-Ciocalteu reagent, $\mathrm{Na}_{2} \mathrm{CO}_{3}$; quercetin, gallic acid, naringin (Sigma-Aldrich, Germany), 2,4dinitrophenylhydrazine (DNPH).

Materials used for immunomodulatory and cytotoxic assays were Roswell Park Memorial Institute (RPMI) 1640 medium (Sigma-Aldrich, Hamburg, Germany), Fetal Bovine Serum (FBS) (Gibco, New York, USA), fungizone (Gibco, New York, USA), penicillinstreptomycin (Pen-Strep) (Sigma-Aldrich, Hamburg, Germany), latex beads $(3 \mu \mathrm{m})$ (Sigma-Aldrich, Hamburg, Germany), Phosphate Buffer Saline (PBS) (Gibco, New York, USA), Giemsa (Merck, Darmstadt, Germany), MTT (3-(4,5-dimethylthiazol-2-yl)-2,5diphenyltetrazolium bromide) (Merck, Germany) and reagent stopper sodium dodecyl sulphate (SDS) (Merck, Germany). Some of the cell lines (HepG2, T47D, Vero, MCF7) where are incubated on their medium proliferation, RPMI 1640 (Sigma-Aldrich, Germany), DMEM, M199.

\section{Sample Preparation}

Faloak barks were identified in the Laboratory of Pharmacognosy, Pharmaceutical Biology Department, Faculty of Pharmacy UGM, Indonesia under Nr. $\mathrm{UGM} / \mathrm{FA} / 1917 / \mathrm{M} / 03 / 02$. After drying in an oven at $50^{\circ} \mathrm{C}$, the samples were pulverized. The decoction was prepared according to the Indonesian Pharmacopeia (1995). The supernatant was collected and freeze-dried. Ethanol extracts were prepared by immersing the pulverized barks in the extraction solvent at a ratio of $1: 6$. After $24 \mathrm{~h}$, the solvent was decanted and the residue was macerated in the same solvent at a ratio of 1:5 for three days. The filtrate was evaporated to yield a thick extract (Siswadi, 2015).

\section{Phytochemical Analysis}

Phytochemical analyses were conducted on the RP18 plate as the stationary phase and for the mobile phase water:acetone:formic acid (5:20:1 v/v/v) was used (Munawaroh et al., 2018). The samples were observed under $\mathrm{UV}_{254}$ and $\mathrm{UV}_{366}$ lights before and after spraying with the reagents $\mathrm{AlCl}_{3}$, ammonia vapor, $\mathrm{Ce}\left(\mathrm{SO}_{4}\right)_{2}$ and DPPH (Jork et al., 1990). The volume of the sample was three $\mu \mathrm{l}$. The UV profile was analyzed using the CAMAG TLC scanner.

Total phenolic contents were evaluated by using Folin Ciocalteau reagent (Singleton et al., 1999) and done in triplicate. The total flavonoid content was measured using 2,4-dinitrophenylhydrazine, with naringin as a standard following flavonoid content identification (Chang et al., 2002).

\section{Macrophage Isolation and Macrophage Phagocytosis Activity Assay in Vitro}

Concentrations used in the immunomodulatory assays were $62.5,125,250,500$ and $1000 \mu \mathrm{g} / \mathrm{mL}$, which were prepared from a stock solution $10 \mathrm{mg} / \mathrm{mL}$.

Macrophage was isolated from mice peritoneal fluid. The number of cells was calculated using a Neubauer hemocytometer, after which they were suspended in complete media to achieve a concentration of $2.5 \times 10^{6}$ cells $/ \mathrm{mL}$. The cell suspension was inoculated on coverslips in 24-well microtiter plates and incubated at 
$37^{\circ} \mathrm{C}$ under $5 \% \quad \mathrm{CO}_{2}$. After adding the complete medium into each well and incubation, latex beads suspended in PBS were added. Following incubation under $5 \% \mathrm{CO}_{2}$ incubator at $37^{\circ} \mathrm{C}$ for $60 \mathrm{~min}$, the cells were rinsed three times with PBS to eliminate excess latex beads and left to dry at room temperature. Then, the cells were fixed using methanol for $30 \mathrm{~s}$. After the coverslips were left to dry, Giemsa $2 \%$ (v/v) was used for staining (Sumardi and Sasmito, 2013). Phagocytosis activity defined as the phagocytosis capacity and the Phagocytosis Index (PI). The number of macrophages phagocytes latex beads and the number of latex beads engulfed by the macrophages was counted under a microscope (Jensch-Junior et al., 2006).

\section{Lymphocyte Isolation and Proliferation Assay in Vitro}

Spleen was aseptically extracted and the cells were counted using hemocytometer under an inverted microscope and were incubated at $37^{\circ} \mathrm{C}$ under $5 \% \mathrm{CO}_{2}$. After suspending the cells in complete medium, each $100 \mu \mathrm{L}$ suspension was added to a 96-well microtiter plate. Afterward, $10 \mu \mathrm{L}$ vaccine hepatitis B was added into each well and the suspension was incubated at $37^{\circ} \mathrm{C}$ for $24 \mathrm{~h}$ under $5 \% \mathrm{CO}_{2}$. Samples were added and incubated for $48 \mathrm{~h}$. Furthermore, MTT (3- (4,5dimethylthiazol-2-yl) -2,5-diphenyltetrazolium bromide) was added into each wells and incubated at $37^{\circ} \mathrm{C}$ for $4 \mathrm{~h}$. Reagent stopper (10\% SDS) in $50 \mu \mathrm{L}$ of $0.01 \mathrm{~N} \mathrm{HCl}$ was added into each well. The stimulation index (SI) was calculated after the optical densities were measured at $550 \mathrm{~nm}$ (Sumardi and Sasmito, 2013).

\section{Cytotoxic Assay in Vitro}

Cell lines were transferred onto micro titer-plate in $1 \times 10^{5}$ cells/well. After incubated for $24 \mathrm{~h}$ in a $\mathrm{CO}_{2}$ incubator, sample diluted on DMSO were added by serial dilution (12.5-200 ppm) then incubated for $24 \mathrm{~h}$ in a $\mathrm{CO}_{2}$ incubator. Controls used were positive control (doxorubicin 12.5-200 ppm), negative control (cell culture), diluted control and medium control. The medium was removed, then put the MTT $5 \mathrm{mg} / \mathrm{mL}$ in PBS solution $100 \mu \mathrm{l} /$ well and incubated for 3-4 h in a $\mathrm{CO}_{2}$ incubator until formazon formed and put the SDS $5 \%$ as a stopper and incubated $24 \mathrm{~h}$. The viability cells were counting by ELISA reader in $545 \mathrm{~nm}$ (Riss et al., 2013).

\section{Statistical Analyses}

Data represented by the mean \pm Standard Deviation (SD) were obtained from triplicate assays and statistically analyzed by SPSS to evaluate the significant difference between treatments. The Shapiro-Wilk test was used to evaluate the normality of data distribution. For normally distributed data, the analyses were continued by variance analyses with the homogeneity of variances. Data having identical variance were analyzed further using one-way ANOVA and LSD tests with a 95\% confidence level $(\mathrm{p}<0.05)$ to evaluate significant differences that may occur among independent variables.

\section{Results}

\section{Phytochemical Analysis}

In order to provide a phytochemical profile of the extracts used in this study and to predict compounds responsible for the activity, several assays have been conducted. The TLC method has been applied to extracts in order to provide information regarding the phytochemical profile of Faloak bark extracts. Water extract, ethanol extract and ethanol-water extract had the same $R_{f}$ at $R_{f} 0.82$. This $R_{f}$ value was similar to the $R_{f}$ of the naringin standard (Fig. 1; Table 1). The profile of each extract exhibited the presence of flavonoids, i.e., flavones following $\mathrm{AlCl}_{3}$ and ammonia favor. All samples exhibited DPPH radical scavenging activity (Fig. 2).

Figure 3 showed the TLC profiles obtained using a TLC scanner, depicting similar profiles of the samples. Comparing the UV profiles of the flavonoids content of the extracts with those of the standards used, i.e., quercetin, naringin and gallic acid has recommended the presence of flavanone compounds, at $R_{f} 0.79-0.86 ; R_{f}$ 0.75-0.83 for water extract, $R_{f}$ 0.75-0.85 for ethanol extract and $R_{f} 0.78-0.84$ for ethanol-water extract. Figure 4 showed the similar UV profiles of spots having hRf 82 observed on all extracts.

Considering that phenolics and flavonoids are major constituents observed from the TLC profile, further analyses on those group of compounds were evaluated. The total flavonoid contents of the extracts used were calculated as \%w/w equivalent naringin (\%NE) as follows; water extract $(8.05 \% \pm 0.20 \%)$, ethanol extract $(11.89 \% \pm 0.28 \%)$, ethanol-water extract $(7.86 \% \pm 0.09 \%)$. The total phenolic contents were calculated as \% equivalent gallic acid (\%GAE) i.e., $12.03 \% \pm 0.50 \%$ (water extract), $22.09 \% \pm 0.71 \%$ (ethanol extract) and $11.61 \% \pm 0.56 \%$ (ethanol-water extract).

\section{Immunomodulatory Activities}

The results of macrophage phagocytosis activity were described in Fig. 5 and 6, which showed that water extract resulted in the highest Phagocytosis Index (PI) and percentage of activated macrophages at $1 \mathrm{mg} / \mathrm{mL}$ (PI $=145.72 \% \pm 0.18 \% ; \%$ active macrophages $=$ $64.89 \% \pm 7.31 \%$ ). However, all the samples showed significant differences when compared with normal control (without treatment) and exhibited a correlation with the concentration applied. These results revealed that the water extract could increase the phagocytosis of macrophages, which, as indicated by the high values of PI and the percentage of activated macrophages. 
Triana Hertiani et al. / OnLine Journal of Biological Sciences 2019, 19 (4): 222.231 DOI: 10.3844/ojbsci.2019.222.231

\begin{tabular}{|c|c|c|c|c|c|c|}
\hline \multirow[b]{2}{*}{ Peak Nr } & \multicolumn{2}{|c|}{ Water extract } & \multicolumn{2}{|c|}{ Ethanol extract } & \multicolumn{2}{|c|}{ Ethanol-water extract } \\
\hline & $\mathrm{hRf}$ & Area $(\%)$ & hRf & Area $(\%)$ & $\mathrm{hRf}$ & Area $(\%)$ \\
\hline 1 & & & 22 & 7.83 & & \\
\hline 2 & & & ing & & 36 & 7.94 \\
\hline 3 & & & & & 53 & 13.7 \\
\hline 4 & 82 & 27.61 & 82 & 34.6 & 82 & 16.7 \\
\hline 5 & 91 & 39.96 & 90 & 31.21 & 90 & 10.29 \\
\hline 6 & & & & & 92 & 11.93 \\
\hline
\end{tabular}

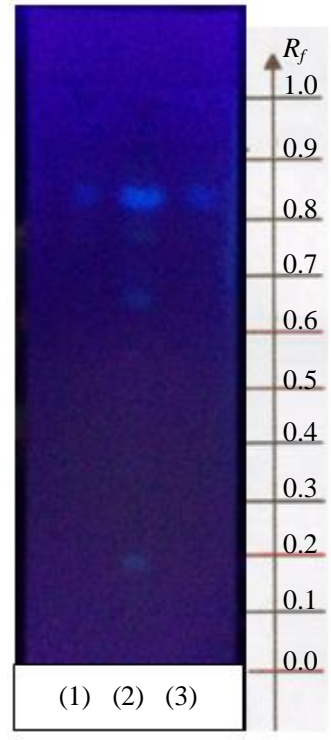

(a)

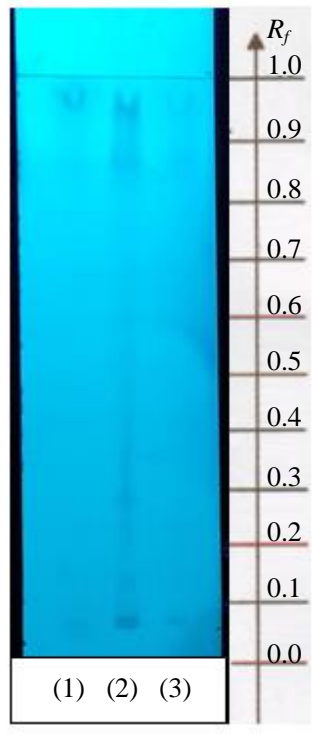

(b)

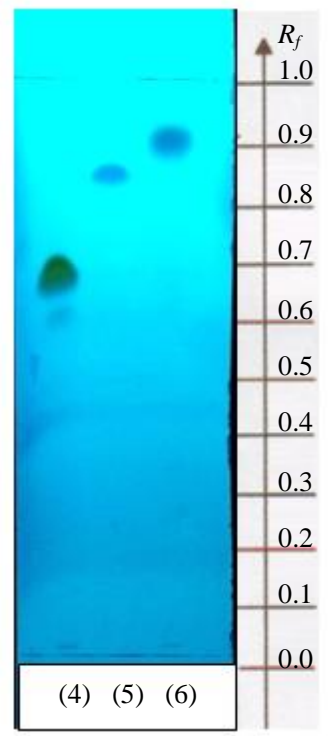

(c)

Fig. 1: TLC profiles of; (1) water extracts; (2) ethanol extract; (3) ethanol-water extract compared to; (4) quercetin; (5) naringin and; (6) gallic acid. Observation under; (a) $\mathrm{UV}_{366}$; (b) and; (c) $\mathrm{UV}_{254}$; TLC system: stationary phase RP-18 $\mathrm{F}_{254}$, mobile phase water: acetone : formic acid $(5: 20: 1 \mathrm{v} / \mathrm{v} / \mathrm{v})$

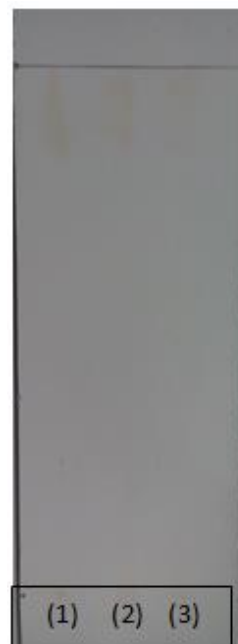

(a)

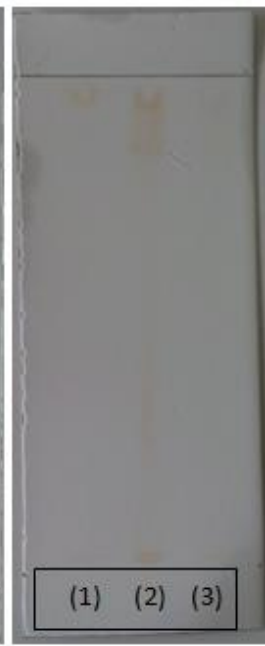

(b)

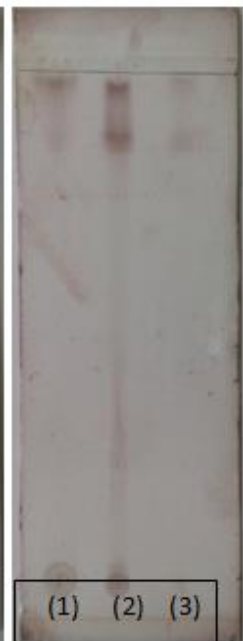

(c)

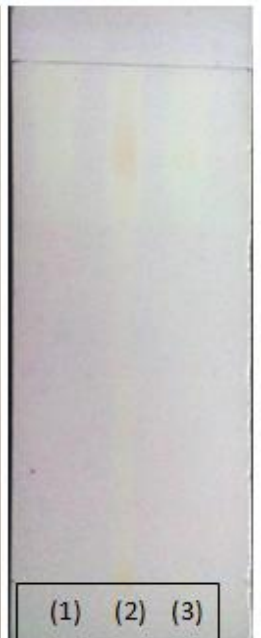

(d)

Fig. 2:TLC profiles of; (1) water extract; (2) ethanol extract; (3) ethanol-water extract after spraying with reagents; (a) $\mathrm{AlCl} 3$; (b) ammonia vapor; (c) $\mathrm{Ce}\left(\mathrm{SO}_{4}\right)_{2}$; (d) DPPH. TLC system: stationary phase RP-18 F254, mobile phase: water : acetone : formic acid $(5: 20: 1 \mathrm{v} / \mathrm{v} / \mathrm{v})$ 


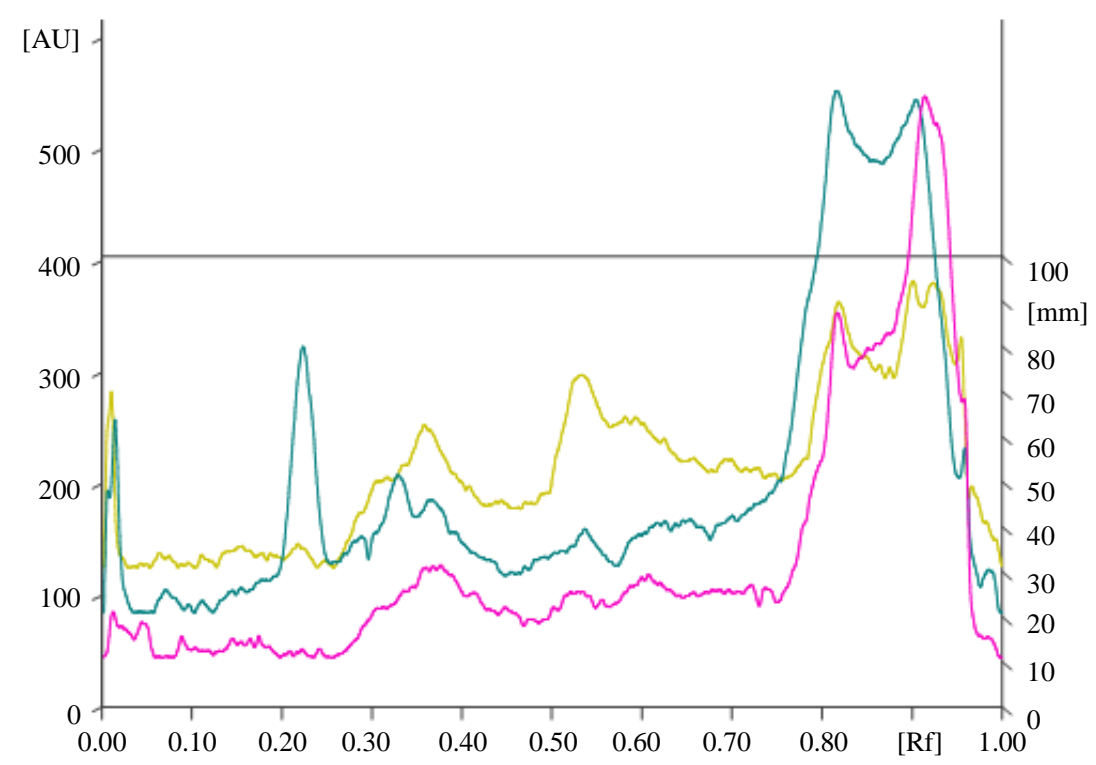

Fig. 3: Chromatogram profile of water extract (pink), ethanol extract (blue) and ethanol-water extract (yellow) observed under UV $254 \mathrm{~nm}$

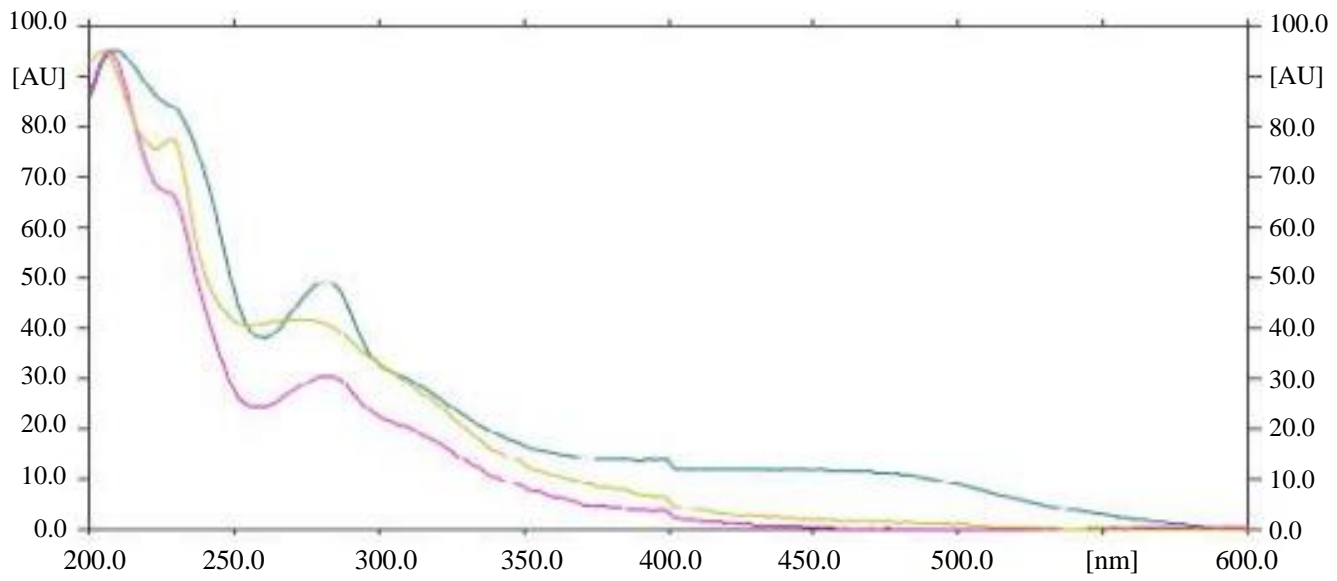

Fig. 4: UV profile of spots having hRf 82 of water extract (pink), ethanol extract (blue) and ethanol-water extract (yellow) scan from $0-600 \mathrm{~nm}$

Lymphocyte proliferation is a process describing lymphocyte response against antigenic stimulation, while lymphocytes specifically recognize and respond to foreign antigens and can behave as mediators of humoral and cellular immunity. The results of the experiment evaluating the effect of the application of the extracts on lymphocyte proliferation showed a proliferation index of $<2$, which indicated that the extracts had no effects at the concentration tested (Fig. 7). A substance can be considered as active in stimulating lymphocyte proliferation if the SI value is > 2, of which a value of 2-3 is considered as weakly positive (Pichler and Tilch, 2004).

In order to identify the bioactive compound group, a correlation analysis of the total contents of phenolic compounds and flavonoids towards macrophage phagocytosis activity was conducted (Fig. 8a). The correlation between total flavonoid content and PI can be described by the equation $\mathrm{y}=-13.32 \mathrm{x}+231.8, r^{2}=$ 0.682 , which implied that the flavonoids contributed to the biological activity by $68.2 \%$ and other compounds may influence the remaining $31.8 \%$ of activity. Figure $8 \mathrm{~b}$ depicted the correlation between the total content of phenolic compounds by equation $\mathrm{y}$ $=-5.107 \mathrm{x}+186.6, r^{2}=0.665$, implying that $66.5 \%$ of the total phenolic contents contributed to the macrophage phagocytosis while the nonphenolic compounds contribute the remaining $33.5 \%$. 


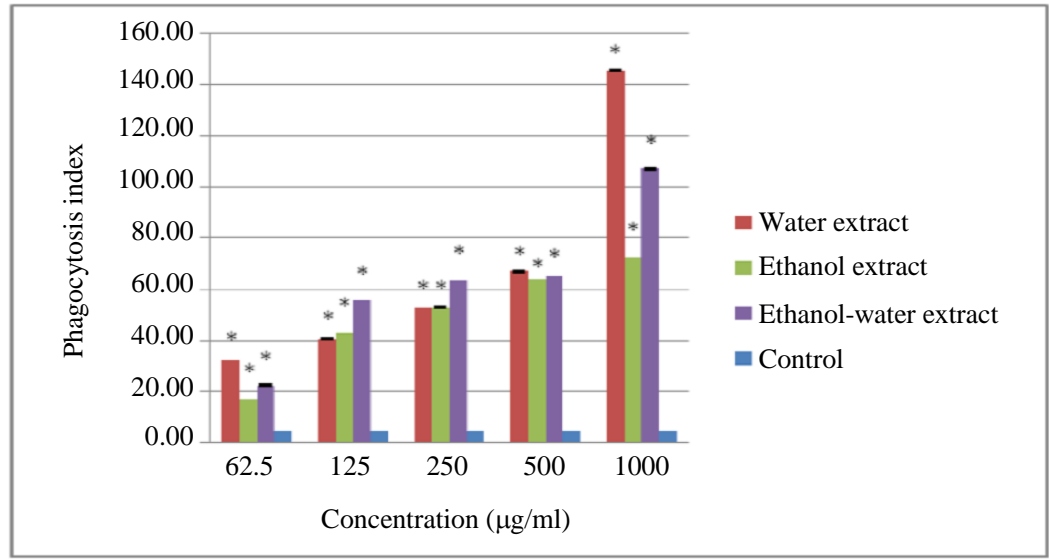

Fig. 5: Phagocytosis index of macrophages against latex beads following sample application. Note: mean $\pm S D, n=3, \alpha=0.05$; *shows significant difference compared with control $(\mathrm{P}<0.05)$

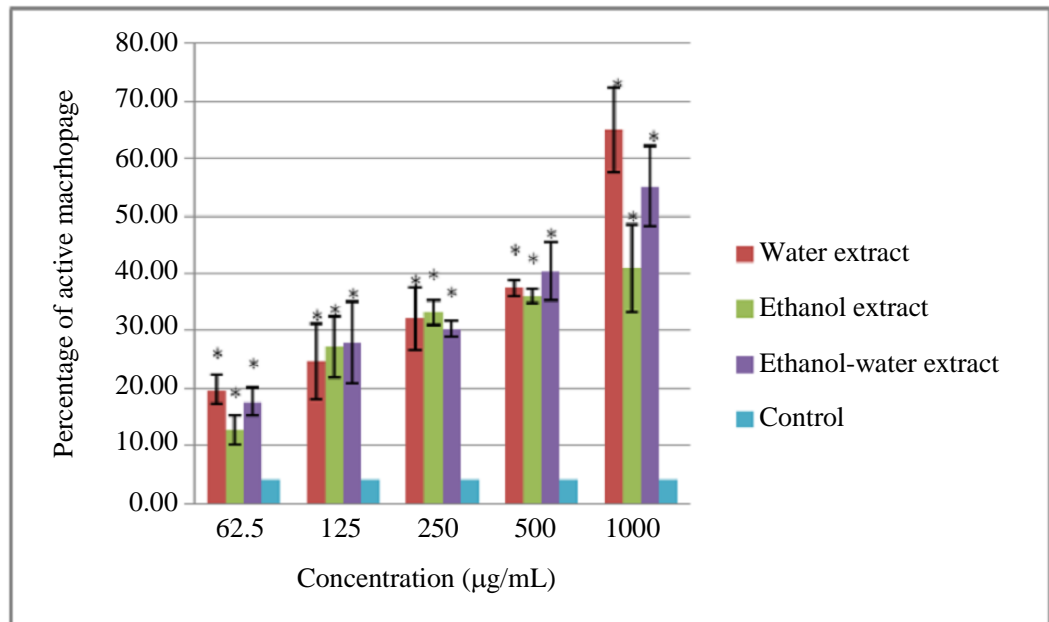

Fig. 6: Percentage of active macrophages against latex beads following sample application. Note: mean $\pm \mathrm{SD}, \mathrm{n}=3, \alpha=0.05$; *shows significant difference compared with control $(\mathrm{P}<0.05)$

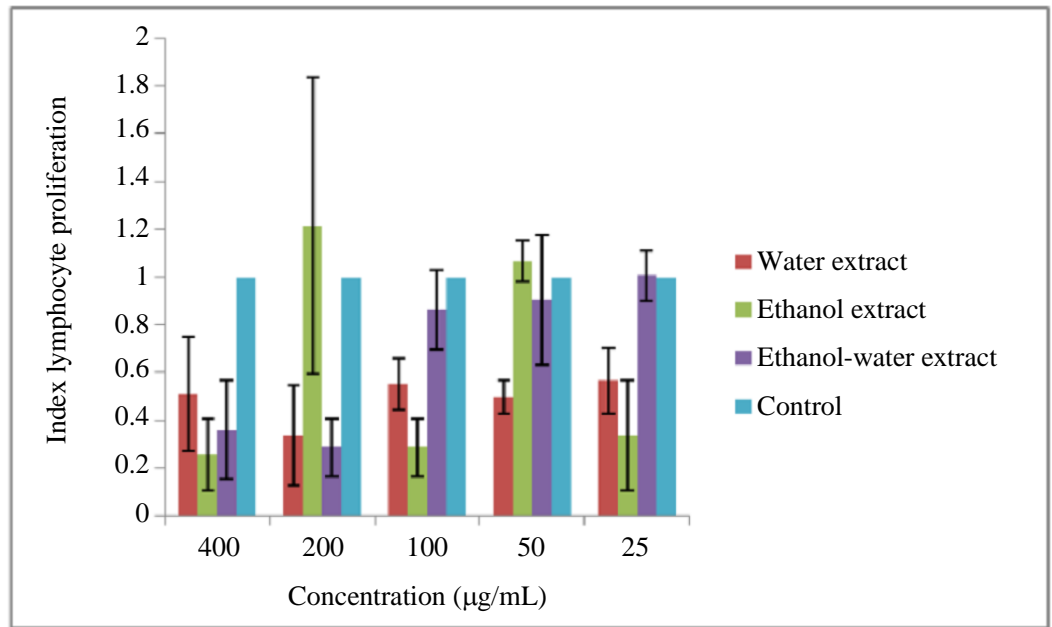

Fig. 7: Lymphocyte proliferation index following sample application. Note: mean $\pm \mathrm{SD}, \mathrm{n}=3, \alpha=0.05$; $*$ shows significant difference compared with control $(\mathrm{P}<0.05)$ 


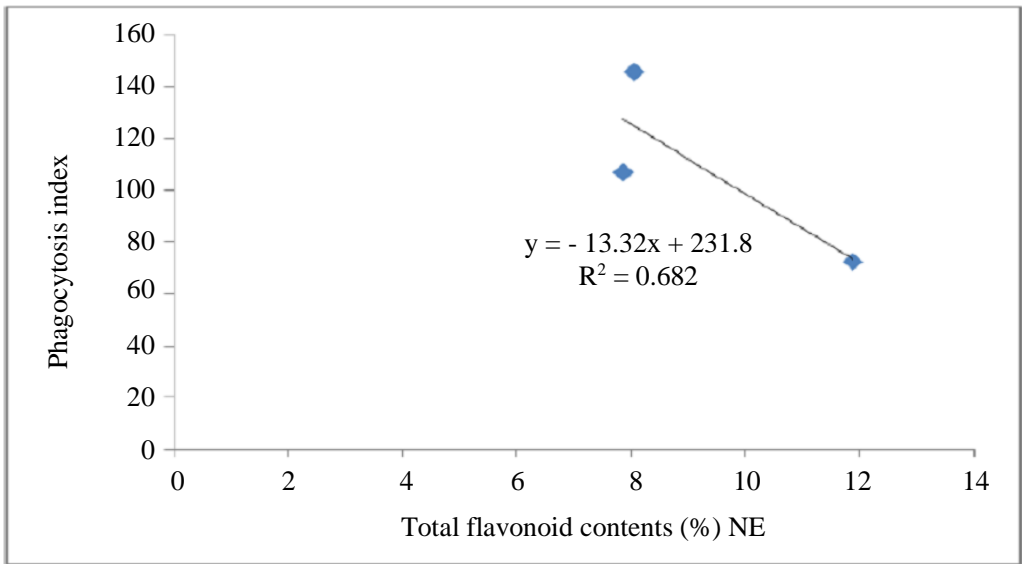

(a)

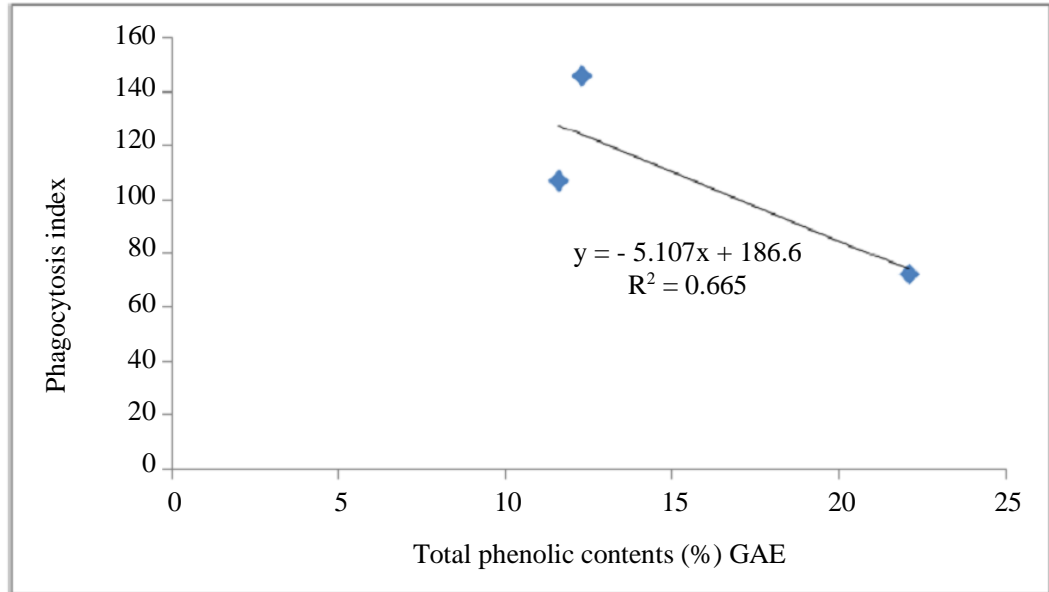

(b)

Fig. 8: Correlation analyses of total flavonoid and total phenolics contents vs. phagocytosis index

Table 2: IC50 of faloak against Vero and HepG2 cell lines

\begin{tabular}{llll}
\hline Extracts & $\begin{array}{l}\text { Vero } \\
(\mu \mathrm{g} / \mathrm{mL})\end{array}$ & $\begin{array}{l}\text { HepG2 } \\
(\mu \mathrm{g} / \mathrm{mL})\end{array}$ & $\begin{array}{l}\text { Selectivity } \\
\text { index }\end{array}$ \\
\hline Water & 18.57 & 1000.06 & 0.02 \\
Ethanol & 334.82 & 44.40 & 7.54 \\
Ethanol-water & 0.07 & 60.37 & 0.002 \\
\hline
\end{tabular}

Table 3: Effects of faloak extract and fractions against different cell lines

\begin{tabular}{lllll}
\hline & IC50 $\mu \mathrm{g} / \mathrm{mL}$ (Selectivity index) & \\
& ----------- & - \\
Samples & T47D & MCF7 & HepG2 & Vero \\
\hline Ethanol Extract & 157.4 & 24.9 & 6.35 & 57.55 \\
& $(0.36)$ & $(2.31)$ & $(9.06)$ & \\
Hexane fraction & $>1000$ & 434.9 & 77.98 & 551.40 \\
& & $(1.27)$ & $(7.07)$ & \\
Ethylacetate fraction & 9.56 & 7.62 & 3.24 & 19.25 \\
& $(2.01)$ & $(2.52)$ & $(5.94)$ & \\
Water fraction & 306 & 809.29 & 28.77 & 128.69 \\
& $(0.42)$ & $(0.16)$ & $(4.47)$ & \\
Residue & 55.52 & 60.85 & 22.99 & 48.12 \\
& $(0.87)$ & $(0.79)$ & $(2.09)$ & \\
Doxorubicin & 70.4 & 53.11 & 1.65 & 846.78 \\
& $(12.02)$ & $(15.94)$ & $(513.2)$ & \\
\hline
\end{tabular}

\section{Cytotoxic Activity}

In this study, the extraction solvent was chosen based on the extract's cytotoxic activity against HepG2 cells and the Selectivity Index against Vero cells (Table 2). Therefore, ethanol extract, which showed the Selectivity Index (SI) 7.54, was used for further assay.

The fractionation on the ethanol extract followed by cytotoxicity assays on several cell lines exhibited that the ethyl acetate fraction has prominent cytotoxic results against T47D and MCF7 cells (compared to doxorubicin). The ethyl acetate fraction also exhibited potential cytotoxic results against HepG2 cells but only approximately half of that of doxorubicin. However, the ethyl acetate fraction exhibited lower Selectivity Index in comparison to doxorubicin (Table 3). The ethyl acetate fraction showed higher cytotoxic activities in comparison to the crude extract.

\section{Discussion}

Faloak barks exhibited a potential effect on the nonspecific immune response. A positive correlation was 
observed between the contents of flavonoids and phenolic compounds and the macrophage phagocytosis activity, although other groups of compounds may contribute to this activity. Flavonoid contributes towards the repair biochemical and pharmacological process of the immune system and the cells related to inflammatory processes, e.g., $\mathrm{T}$ cells, B cells, macrophages, neutrophils, mast cells and basophils. This group of compounds possesses the ability to influence the process of inflammation. Such enzymes play a role in signal transduction and $\mathrm{T}$ cell proliferation processes, B cell activation, or the production of cytokines that stimulate monocytes (García-Lafuente et al., 2009).

Munawaroh et al. (2018) support the finding that flavonoid contributes to the macrophage phagocytosis activity of the ethyl acetate fraction. However, beside flavonoids and phenolics compounds, other constituents may also influence the activity. The faloak bark contains saponin and triterpenoids (Ranta, 2011; Siswadi, 2015). It has been reported that several steroids and triterpenoids such as lupeol, lupenone and betulinic acid (pentacyclic triterpene); steroids such as sitosterol, stigmasterol, lupenone, have been isolated from a closely related plant, Sterculia striata (Costa et al., 2010). Sutomo et al. (2013) reported that lupeol could increase macrophage phagocytosis. Lupeol from Sterculia villius was reported as a potential antileishmanial and immunomodulator, as shown by nitric oxide generation induction in L. donovani-infected macrophage following lupeol application (Das et al., 2017). Winanta et al., (2019) has also observed activation of NO production on macrophage following Faloak bark decoct treatment.

Furthermore, triterpenoids and saponins possess immunomodulatory activity as assessed by an in vitro technique (Mali and Hatapakki, 2008). Hendriks et al. (2003) confirmed that some flavonoid isolates, i.e., luteolin, quercetin and fisetin, could reduce the phagocytosis of myelin by macrophage in a multiple sclerosis neuroinflammatory disease model and concluded that the antioxidant activity is closely related to cell phagocytosis.

Consistent with the result in the cytotoxicity assay, the ethyl acetate fraction is the most active in stimulating the phagocytosis of mice macrophages (Munawaroh et al., 2018). It was identified that the spot having hRf 82 was also found in the ethyl acetate fraction but missing in others (Munawaroh et al., 2018). An earlier study had reported the isolation of naphthoquinone compound from the ethyl acetate fraction which showed potential effects against T74D cells (Rollando and Alfanaar, 2017). This group of compounds may also be responsible for the immunomodulator and cytotoxicity properties of the fraction. A recent finding reveals the presence of epicatechin in the faloak stem bark water extract. This compound is suggested as the bioactive responsible for the extract inhibition on hepatitis C virus (VHC JFH1) and showed high selectivity index towards a hepatocyte cell line, Huh7it cell (Dean et al., 2019).

\section{Conclusion}

Faloak extract and fractions exhibit promising effects in stimulating macrophage phagocytosis activity. The ethyl acetate fraction of Faloak bark could further be investigated as a herbal for cancer chemopreventive based on its prominent cytotoxic effects against T47D, MCF7 and HepG2 cells, of which the selectivity index being $>2$ and as a promising immunomodulator.

\section{Acknowledgment}

The authors acknowledge Dr. Djoko Santoso for the identification of the plant sample. The research funding from the Indonesia Ministry of Research and Technology-Higher Education (Hibah Penelitian Berbasis Kompetensi 2018-2019) is gratefully acknowledged. "The authors would like to thank Enago (www.enago.com) for the English language review." Parts of study on extracts were used for the Master thesis of A.W. under the supervision of T.H. and P.

\section{Author's Contributions}

Triana Hertiani: Principal investigator.

Purwantiningsih: Designing immunology assay.

Aji Winanta: Conducting immunology assay and phytochemical analyses.

Widyandani Sasikirana: Conducting cytotoxicity assay and analyses.

Rima Munawaroh: Conducting phytochemical preparation.

Erna Prawita Setyowati: Designing phytochemical assay.

Retno Murwanti: Designing cytotoxicity assay.

Siswadi: Sample preparation.

\section{Ethics}

This manuscript has not been published elsewhere in part or in entirely and is not under consideration by another journal. All the authors have approved the manuscript and agree with submission to this journal. Authors declare that are not ethical issues and no conflict of interest that may arise after the publication of this manuscript.

\section{References}

Bhat, H.P., R.P. Jakribettu, R. Boloor, R. Fayad and M.S. Baliga, 2015. Use of Ayurvedic Medicinal Plants as Immunomodulators in Geriatrics. In: Foods and Dietary Supplements in the Prevention and Treatment of Disease in Older Adults, Watson, R.R. (Ed.), Academic Press, Elsevier, Amsterdam, pp: 143-149. 
Chang, C.C., M.H. Yang, H.M. Wen and J.C. Chern, 2002. Estimation of total flavonoid content in propolis by two complementary colorimetric methods. J. Food Drug Anal., 10: 178-182.

Costa, D.A., M.H. Chaves, W.C.S. Silva and C.L.S. Costa, 2010. Constituintes químicos, fenóis totais e atividade antioxidante de Sterculia striata St. Hil. et Naudin. Acta Amazonica, 40: 207-212. DOI: $10.1590 /$ S0044-59672010000100026

Das, A., J.J. Jawed, M.C. Das, A. Daware and C. Ghosh et al., 2017. Antileishmanial and immunomodulatory activities of lupeol, a triterpene compound isolated from Sterculia villosa. Int. J. Antimicrobials, 50: 512-522.

DOI: 10.1016/j.ijantimicag.2017.04.022

Dean, M., R. Handajani and J. Khotib. 2019. Faloak (Sterculia quadrifida R.Br.) stem bark extract inhibits hepatitis c virus JFH1. Oriental J. Chem., 35: 430-435. DOI: $10.13005 /$ ojc/350155

García-Lafuente, A., E. Guillamón, A. Villares, M.A. Rostagno and J.A. Martínez, 2009. Flavonoids as anti-inflammatory agents: Implications in cancer and cardiovascular disease. Inflammat. Res., 58: 537-552. DOI: 10.1007/s00011-009-0037-3

Hendriks, J.J.A., H.E. de Vries, S.M.A. van der Pol, T.K. van den Berg and E.A.F. van Tol et al., 2003. Flavonoids inhibit myelin phagocytosis by macrophages; A structure-activity relationship study. Biochem. Pharmacol., 65: 877-885.

DOI: 10.1016/S0006-2952(02)01609-X

Hertiani, T., P. Permanasari, H. Mashar and Siswadi, 2017. Preliminary study on faloak bark potency for prevention of microbial infection. Proceeding of the Conference on Health Management in Post Disaster Recovery "Strengthening Healthcare System Capacity to Disaster: Towards a Sustainable Risk Reduction", May 22-23, IEEE Explore Press, Unsyiah, Indonesia, pp: 59-66.

Jensch-Junior, B.E., L.N. Pressinotti, J.C.S. Borges and J.R.M.C. da Silva, 2006. Characterization of macrophage phagocytosis of the tropical fish Prochilodus scrofa (Steindachner, 1881). Aquaculture, 251: 509-515. DOI: 10.1016/j.aquaculture.2005.05.042

Jork, H., W. Funk, W. Fischer and H. Wimmer, 1990. Thin Layer Chromatography: Reagents and Detection Methods. Physical and Chemical Detection Methods: Fundamentals, Reagents I. 1st Edn., VCH, New York. ISBN: 0895738767, pp: 147.

Magrone, T., S. Fontana, F. Laforgia, T. Dragone and E. Jirillo et al., 2016. Administration of a polyphenolenriched feed to farmed sea bass (Dicentrarchus labrax L.) modulates intestinal and spleen immune responses. Oxidative Med. Cellular Longevity, 216: 1-11. DOI: $10.1155 / 2016 / 2827567$
Mali, R.G. and B.C. Hatapakki, 2008. An in vitro study of effect of Centella asiatica on phagocytosis by human neutrophils. Int. J. Pharmaceut. Sci. Nanotechnol., 1: 297-302.

Munawaroh, R., S. Siswadi, E.P. Setyowati, R. Murwanti and T. Hertiani, 2018. Correlation between total flavonoid contents and macrophage phagocytosis activity of fractions from faloak (Sterculia quadrifida R.Br.) barks ethanolic extract in vitro. Traditional Med. J., 23: 47-55.

DOI: $10.22146 /$ mot.30882

Pichler, W.J. and J. Tilch, 2004. The lymphocyte transformation test in the diagnosis of drug hypersensitivity. Allergy, 59: 809-820. DOI: 10.1111/j.1398-9995.2004.00547.x

Ranta, F., 2011. Antimicrobial activity of extractive of faloak (Sterculia comosa Wallich). MSc Thesis, Institut Pertanian Bogor, Bogor, Indonesia.

Riss, T.L., R.A. Moravec, A.L. Niles, S. Duellman and H.A. Benink et al., 2013. Cell Viability Assay. In: Assay Guidance Manual, Sittampalam, G.S., N.P. Coussens and K. Brimacombe (Eds.), Eli Lilly Company and the National Center for Advancing Translational Sciences, Bethesda, pp: 357-363.

Rollando, R. and R. Alfanaar, 2017. Isolasi senyawa turunan naptokuinon dari kulit batang faloak (Sterculia quadrifida R.Br.) dan uji aktivitas antikanker pada sel kanker payudara jenis T47D. Cakra Kimia, 5: 12-17. DOI: 10.24843/CK.2017.v05.i01.p02

Santangelo, C., R. Varì, B. Scazzocchio, R. Di Benedetto and C. Filesi et al., 2007. Polyphenols, intracellular signalling and inflammation. Annali dell'Istituto Superiore di Sanita, 43: 394-394.

Singleton, V.L., R. Orthofer and R.M. LamuelaRaventos, 1999. Analysis of total phenol and other oxidation substrates and antioxidants by means of folin-ciocalteu reagent. Meth. Enzymol., 299: 152-178. DOI: 10.1016/S0076-6879(99)99017-1

Siswadi, S., 2015. Rendemen ekstrak dan flavonoid total kulit batang pohon faloak (Sterculia quadrifida $\mathrm{R}$. Br.) pada beberapa kelas diameter dan strata ketinggian tempat tumbuh. MSc Thesis, Universitas Gadjah Mada, Yogyakarta, Indonesia.

Siswadi, S., H. Rianawati, G.S. Saragih and D.S. Hadi, 2014. The Potency of faloak's (Sterculia quadrifida R.Br.) active compunds as natural remedy. Proceedings of the International Seminar Forests Medicinal Plants for Better Human Welfare, Sep. 10-12, Center for Forest Productivity Research and Development, Indonesia, pp: 73-79. 
Sumardi, S., T. Hertiani and E. Sasmito, 2013. Ant plant (Myrmecodia tuberosa) hypocotyl extract modulates $\mathrm{TCD}^{4+}$ and $\mathrm{TCD}^{8+}$ cell profile of doxorubicin-induced immune-suppressed sprague dawley rats in vivo. Scientia Pharmaceut., 81: 1057-1069. DOI: 10.3797/scipharm.1302-03

Sutomo, S., S. Wahyuono, S. Rianto and E.P. Setyowati, 2013. Isolation and identification of active compound of $\mathrm{n}$-hexane fraction from kasturi (Mangifera casturi Konsterm.) against antioxidant and immunomodulatory activity. J. Biol. Sci., 13: 596-604. DOI: 10.3923/jbs.2013.596.604
Winanta, A., T. Hertiani, P. Purwantiningsih and S. Siswadi, 2019. In vivo immunomodulatory activity of faloak bark extract (Sterculia quadrifida R.Br). Pak. J. Biol. Sci., 22: 590-596.

DOI: $10.3923 /$ pjbs.2019.590.596 